\title{
TINGKAT KEMAMPUAN BERPIKIR KREATIF MATEMATIS SISWA SISWA SMAN DI SURABAYA
}

\author{
Tri Dyah Prastitia ${ }^{a}$,Sri Tresnaningsih ${ }^{b}$, Jackson Pasini Mairing ${ }^{c}$ \\ ${ }^{a}$ Program Studi Pendidikan Matematika FKIP UPPBJ UT Surabaya \\ Kampus C UNAIR, Jln Mulyorejo Surabaya, tridyahprastiti@gmail.com \\ ${ }^{b}$ Program Studi Pendidikan Matematika FKIP UPPBJ UT Surabaya, \\ Kampus C UNAIR, Jln Mulyorejo Surabaya, sritresnaningsih@ecampus.ut.ac.id \\ 'Program Studi Pendidikan Matematika UPR \\ Jl. H Timang Kampus UPR Palangka Raya, jacksonmairing@gmail.com
}

\begin{abstract}
ABSTRAK
Penelitian ini bertujuan untuk mendeskripsikan Tingkat Kemampuan Berpikir Kreatif (TKBK) Matematis siswa kelas XI dari SMAN terakreditasi A di kota Surabaya. Peneliti mengembangkan dua masalah matematika materi lingkaran dimana siswa-siswa diminta untuk menyelesaikan dengan cara yang berbeda di setiap masalah. Subjek penelitian ini adalah 186 siswa SMAN 2 Surabaya, dimana kedua masalah yang telah dikembangkan tersebut dibagikan kepada subjek penelitian. Penyelesaian siswa dinilai menggunakan rubrik holistik kemudian diidentifikasi ketercapaian dari tiga indikator berpikir kreatif. Indikator tersebut adalah kefasihan, fleksibilitas dan kebaruan. Hasilnya menunjukkan bahwa siswa-siswa tersebut dimana yang tergolong sangat kreatif (TKBK 4), kreatif (TKBK 3), cukup kreatif (TKBK 2), kurang kreatif (TKBK 1) atau tidak kreatif (TKBK 0) secara berturut-berturut sebanyak 5,4 \%; 8,6\%; 5,9\%, 67,7\% dan 12,4\%. Dengan kata lain, 80,1\% siswa-siswa tersebut tergolong kurang kreatif dan tidak kreatif. Kondisi tersebut terjadi karena kebiasaan penyelesaian siswa-siswa didasarkan pada rumus-rumus yang dipelajarinya di kelas. Banyak siswa yang kurang berani mengembangkan kreatifitas berpikir lebih jauh dari bekal yang sudah dimilikinya.
\end{abstract}

Kata Kunci : Berpikir Kreatif, Fleksibilitas, Kebaruan, Kefasihan, Masalah Matematika.

\begin{abstract}
The study aimed to describe the creative mathematical thinking (TKBK) level of XI class students in the "A" accredited high school in Surabaya. Researchers developed two mathematical problems specified in math circles, in which students were asked to solve the problems differently. The subjects of this study were 186 students of Senior High School 2 Surabaya, their solutions were rated based on a holistic rubric. Each completions were also identified based on three creative thinking indicators, which were fluency, flexibility, and innovation. The results showed $5.4 \%$ of students were classified as very creative (TKBK4); 8.6\% were classified as creative (TKBK 3); 5.9\% were classified as moderate creative (TKBK 2); $67.7 \%$ were classified as less creative (TKBK 1); and $12.4 \%$ were classified as not creative (TKBK 0);. In other words, $80.1 \%$ of students were classified as less creative and not creative. The condition happened allegedly caused by students' dependency to the formulas taught in class, thus didn't encourage students to develop their creative thinking.
\end{abstract}

Keywords : Creative Thinking, Flexibility, Innovation, Fluently, Mathematic Problems. 


\section{Pendahuluan}

Kemampuan berpikir dalam matematika dibagi atas berpikir memanggil, dasar, kritis dan kreatif. Berpikir memanggil adalah berpikir yang diarahkan untuk memanggil informasi yang telah diingat atau dipelajari sebelumnya oleh siswa. Contoh soal dengan berpikir ini adalah "sebutkan bentuk umum dari persamaan lingkaran?". Siswa mampu menjawab soal ini dengan segera tanpa perlu melakukan aktivitas kognitif tertentu jika pengetahuan mengenai bentuk umum tersebut ada dalam pikiran siswa. Berpikir dasar adalah berpikir yang diarahkan untuk menerapkan suatu aturan atau rumus tertentu secara langsung dalam menjawab soal tertentu. Contohnya "Tentukan jarijari dari lingkaran dengan persamaan ". Jika siswa memiliki pengetahuan bentuk umum mengenai persamaan lingkaran berdasarkan dan mengetahui bahwa adalah titik pusat dari lingkaran tersebut, maka siswa dapat menjawabnya". Soal ini lebih dari soal dengan berpikir memanggil. Akan tetapi, kedua kemampuan ini masih tergolong kemampuan berpikir tingkat rendah (Krulik, Rudnick, \& Milou, 2003).

Kemampuan berpikir kritis dan kreatif berbeda dengan sebelumnya dimana keduanya tergolong kemampuan berpikir tingkat tinggi. Berpikir kritis adalah berpikir yang diarahkan untuk memecahkan masalah-masalah matematika (King, Goodson, \& Rohani, 2016). Masalah matematika dalam berpikir ini berbeda dengan soal di dua berpikir sebelumnya. Soal sebelumnya sering disebut dengan soal rutin sedangkan masalah matematika bukanlah soal rutin tetapi soal matematika dimana cara untuk menyelesaikannya tidak segera dapat dilihat siswa (Polya, 1973; Posamenteir \& Krulik, 2009). Contohnya adalah "tentukan persamaan garis yang tegak lurus dengan garis yang melalui titik $(0,1)$ dan $(3,0)$, dan garis tersebut membagi lingkaran sama besar". Masalah ini tidak dapat diselesaikan hanya dengan menerapkan rumus-rumus tertentu. Siswa perlu membentuk gambar mental, dan mengelaborasi konsep-konsep yang relevan, pengalaman dan strategi atau pendekatan pemecahan masalah untuk mengembangkan rencana pemecahan masalah. Dengan demikian, siswa tidak segera dapat melihat cara penyelesaian suatu masalah.

Berpikir kreatif adalah berpikir yang diarahkan untuk menentukan jawaban atau cara penyelesaian berbeda dari suatu masalah matematika. Siswa 
dapat mencapai tingkat ini setelah mampu menyelesaikan suatu masalah dan berpikir lebih lanjut untuk menentukan jawaban atau cara berbeda dari masalah tersebut. Dengan kata lain, berpikir kreatif dapat dicapai setelah siswa mencapai berpikir kritis. Contoh soal dengan berpikir ini adalah "suatu lingkaran menyinggung garis . Tentukan nilai . Adakah cara lain untuk menentukan nilai ? Jika ada, selesaikan dengan cara tersebut".

Tingkat kemampuan berpikir kreatif yang disingkat dengan TKBK itu sendiri terdiri dari 5 yaitu sangat kreatif (TKBK 4), kreatif (TKBK 3), cukup kreatif (TKBK 2), kurang kreatif (TKBK 1) atau tidak kreatif (TKBK 0). Ada tiga indikator yang menentukan siswa masuk dalam tingkat tertentu yaitu kefasihan, fleksibilitas dan kebaruan. Siswa dikatakan memenuhi indikator kefasihan jika ia mampu atau fasih (lancar) dalam menemukan jawaban dari masalahmasalah matematika. Siswa dikatakan memenuhi indikator fleksibilitas jika ia mampu menemukan cara lain (fleksibel) dalam menyelesaikan suatu masalah. Siswa dikatakan memenuhi indikator kebaruan jika cara yang digunakan dalam menyelesaikan masalah tidak biasa dibuat siswa pada umumnya. Penentuan siswa dalam TKBK tertentu didasarkan pada Tabel 1 (Siswono, 2008).

Tabel 1. Penjenjangan TKBK

\begin{tabular}{|c|c|c|c|c|c|c|c|c|}
\hline Aspek-aspek & \multicolumn{2}{|c|}{ TKBK 4} & \multicolumn{2}{|c|}{ TKBK 3} & \multicolumn{2}{|c|}{ TKBK 2} & TKBK 1 & TKBK 0 \\
\hline Kefasihan & $\sqrt{ }$ & - & $\sqrt{ }$ & $\sqrt{ }$ & - & - & $\sqrt{ }$ & - \\
\hline Fleksibilitas & $\sqrt{ }$ & $\sqrt{ }$ & $\sqrt{ }$ & - & $\sqrt{ }$ & - & - & - \\
\hline Kebaruan & $\sqrt{ }$ & $\sqrt{ }$ & - & $\sqrt{ }$ & - & $\sqrt{ }$ & - & - \\
\hline
\end{tabular}

Keterangan: Siswa tergolong TKBK 4 jika memenuhi ketiga indikator (sebelah kiri), atau memenuhi indikator fleksibilitas dan kebaruan (sebelah kanan)

Berdasarkan uraian di atas dapat disimpulkan bahwa berpikir kreatif adalah berpikir tertinggi dalam matematika. Siswa-siswa diharapkan dapat memiliki kemampuan berpikir ini melalui belajar memecahkan masalah-masalah matematika menggunakan lebih dari satu cara. Pemecahan masalah matematika merupakan tujuan utama siswa-siswa belajar matematika karena melaluinya siswa-siswa dapat memperoleh kemampuan memecahkan masalah, berpikir kritis, dan sikap-sikap positif. Sikap-sikap tersebut adalah tekun, pantang menyerah, dan percaya diri dalam situasi yang tidak biasa. Salah satu pembelajaran yang dapat digunakan untuk mencapai tujuan tersebut adalah pembelajaran yang menggunakan masalah-masalah matematika (Prastiti, 
2017). Berpikir kreatif adalah berpikir tertinggi dalam matematika. Siswa -siswa diharapkan dapat memiliki kemampuan berpikir ini melalui belajar memecahkan masalah masalah matematika menggunakan lebih dari satu cara. Dengan demikian berpikir kreatif dipengaruhi oleh kemampuan siswa dalam memecahkan masalah. Kemampuan siswa dalam memecahkan soal matematika terbagi dalam tiga golongan, yaitu 1) sebagai pemecahan masalah yang baik; 2) menyelesaikan soal yang rutin dan yang 3) golongan siswa yang kurang berpengalaman. Hasil penelitian menunjukkan 96,9\% siswa-siswa kelas $\mathrm{X}$ MIA dari salah satu SMA Negeri di kota Palangka Raya tergolong pemecah masalah yang rutin; 3,1\% tergolong pemecahan masalah yang non rutin dan tidak ada yang tergolong pemecah masalah yang baik (Mairing, 2017). Hasil penelitian dengan tujuan mengidentifikasikan TKBK siswa-siswa kelas X dari salah SMA Negeri di kota Sidoarjo menunjukkan bahwa persentase siswa dengan TKBK 4, 3, 2, 1, dan 0 secara berturut-turut sebesar $0 \%, 2,78 \%$; 2,78\%; 50\%, dan 44,44\% (Mahendra, 2015).

Guru dapat membantu siswa untuk memperoleh kemampuan berpikir kreatif. Caranya dengan menerapkan pembelajaran yang sesuai dengan TKBK siswa-siswa saat ini. Jika sebagian besar siswa berada di TKBK 0 atau 1, maka guru menerapkan pembelajaran yang menekankan pada pembimbingan siswasiswa di setiap tahap pemecahan masalah agar siswa-siswa lancar (fasih) dalam memecahkan masalah dan memberi kesempatan bagi mereka untuk menyelesaikan beragam tipe masalah dengan pendekatan atau strategi yang berbeda-beda. Sebagai contoh, pemecahan masalah real dalam kehidupan sehari-hari sesungguhnya merupakan bagian dari penerapan matematika sekolah. Banyak konsep matematika yang digali dari kehidupan real dan konsepkonsep itu dikembangkan agar dapat digunakan untuk memecahkan masalahmasalah real (Prastiti, 2009). Karena itu salah satu contoh melatih siswa siswa berpikir kreatif bisa dengan pendekatan pembelajaran matematika realistik. (Prastiti, 1997).

Penelitian ini bertujuan untuk mendeskripsikan TKBK siswa-siswa kelas XI SMAN 2 Surabaya dengan akreditasi A tahun ajaran 2017/2018. Hasilnya dapat dimanfaatkan sebagai dasar bagi guru guru matematika untuk mengembangkan rencana pembelajaran yang dapat membantu siswa-siswa untuk meningkatkan kemampuan berpikir kreatifnya. 


\section{Metode Penelitian}

Penelitian ini dilakukan dengan pendekatan kuantitif dengan jenis penelitian deskriptif. Tahap pertama penelitian ini adalah mengembangkan dua masalah matematika dengan materi lingkaran untuk siswa klas XI SMA.. Kedua soal tersebut tergolong masalah berakhir terbuka (open ended) yaitu masalah yang memiliki lebih dari satu jawaban atau lebih dari satu cara penyelesaian (Beck, et al., 2000; Bush \& Greer, 1999).

1. a. Suatu lingkaran $x^{2}+y^{2}-$ $2 a x-8 y+16=0$ menyinggung garis $x=6$. Tentukan nilai $a$.

b. Adakah cara lain untuk menentukan nilai $a$ ? Jika ada, selesaikan dengan cara tersebut.

2. a. Tentukan persamaan garis singgung lingkaran $x^{2}+y^{2}=9$ dengan gradien 1.

b. Adakah cara lain untuk menentukan garis singgung tersebut? Jika ada, selesaikan dengan cara tersebut.

Tahap kedua adalah peneliti membagikan kedua masalah tersebut ke subjek penelitian yaitu siswa-siswa kelas XI SMAN 2 Surabaya sebanyak 186 siswa. Masalah 1 dan 2 berkaitan dengan materi lingkaran. Peneliti memilih materi ini karena subjek dalam penelitian ini baru saja belajar materi tersebut di kelas.

Tahap ketiga adalah peneliti mengidentifikasi TKBK setiap siswa berdasarkan tulisan penyelesaiannya pada masalah 1 dan 2. Tahap pertama untuk tujuan tersebut adalah menskor penyelesaian siswa pada nomor 1(a), 1(b), 2(a) dan 2(b). Setiap nomor tersebut diskor menggunakan rubrik holistik pada Tabel 2 (Charles, Lester, \& O'Daffer, 1987; Sa'dijah \& Sukoriyanto, 2015). Tahap kedua, peneliti mengidentifikasi ketercapaian indikator TKBK dengan ketentuan yaitu kefasihan dipenuhi jika nomor 1(a) atau 2(a) memperoleh skor 4. Fleksibilitas terpenuhi jika nomor 1(b) dan 2(b) memperoleh skor 4. Kebaruan terpenuhi jika setidaknya ada satu cara penyelesaian yang dibuat siswa berbeda dibandingkan dengan cara yang dibuat teman-temannya. Tahap ketiga, peneliti menentukan TKBK setiap siswa berdasarkan Tabel 1. Hasil identifikasi tersebut kemudian dideskripsikan apa adanya oleh peneliti. 
Tabel 2. Rubrik Holistik Pemecahan Masalah

\begin{tabular}{|c|c|}
\hline Skor & Deskripsi \\
\hline $\mathbf{0}$ & $\begin{array}{l}\text { a. Siswa tidak menulis apa pun pada lembar penyelesaian, } \\
\text { b. Siswa menulis yang diketahui dan ditanya, tetapi tidak menunjukkan pemahaman terhadap } \\
\text { masalah. }\end{array}$ \\
\hline 1 & $\begin{array}{l}\text { a. Siswa menulis yang diketahui dan ditanya dengan benar, ada langkah-langkah penyelesaian, } \\
\text { tetapi cara yang digunakan tidak sesuai. } \\
\text { b. Siswa telah berusaha untuk mencapai subtujuan, tetapi tidak berhasil. } \\
\text { c. Siswa menjawab dengan benar, tetapi tidak ada caranya. }\end{array}$ \\
\hline 2 & $\begin{array}{l}\text { a. Siswa menggunakan cara yang tidak sesuai dan jawabannya salah, tetapi penyelesaiannya } \\
\text { menunjukkan beberapa pemahaman terhadap masalah. } \\
\text { b. Siswa menulis jawaban yang benar, tetapi caranya tidak dapat dipahami/salah. }\end{array}$ \\
\hline 3 & $\begin{array}{l}\text { a. Siswa telah menerapkan suatu cara yang sesuai, tetapi salah memahami bagian tertentu dari } \\
\text { masalah, atau mengabaikan suatu kondisi dari masalah. } \\
\text { b. Siswa telah menerapkan suatu cara penyelesaian yang sesuai, tetapi - } \\
\text { (i) menjawab masalah secara tidak benar tanpa penjelasan. } \\
\text { (ii) tidak menuliskan jawabannya. } \\
\text { c. Siswa menuliskan jawaban benar, dan ada beberapa bukti yang menunjukkan bahwa siswa } \\
\text { tersebut telah memilih cara yang sesuai, tetapi penerapan dari cara tersebut tidak sepenuhnya } \\
\text { benar. }\end{array}$ \\
\hline 4 & $\begin{array}{l}\text { a. Siswa telah menggunakan cara yang sesuai, mengimplementasikan dengan benar, dan } \\
\text { menuliskan jawaban yang benar. } \\
\text { b. Siswa menggunakan cara yang sesuai, menulis jawaban yang benar, tetapi ada sedikit kesalahan } \\
\text { dalam perhitungan. }\end{array}$ \\
\hline
\end{tabular}

\section{Hasil dan Pembahasan}

\section{Peneliti membagikan}

kedua masalah kepada semua subjek penelitian. Masalah tersebut dibagikan oleh gurunya. Tujuannya agar siswa-siswa bersungguh-sunguh dalam menyelesaikan kedua masalah sehingga tulisan penyelesaiannya menunjukkan kemampuan berpikir kreatif siswa yang sebenarnya. Peneliti menunggu di sekolah hingga siswa-siswa selesai menyelesaikan kedua masalah.

Langkah pertama, peneliti menskor setiap penyelesaian siswa menggunakan rubrik holistik. Rentang skor masalah 1(a), 1(b), 2(a) dan 2(b) adalah 0 sampai 4 (Tabel 2), sehingga maksimum skor setiap siswa sebesar 16 .
Hasilnya menunjukkan bahwa rata-rata skor siswa dalam menyelesaikan masalah sebesar 10,06, jika dikonversi ke skala 100 menjadi 62,87. Lebih lanjut, rata-rata skor di masalah 1(a), 1(b), 2(a) dan 2(b) secara berturut-turut sebesar 2,84; 1,91; 3,18 dan 2,12 (Tabel 3). Jika dikonversi ke skala 100 menjadi: 70,97; 47,85; 79,57 dan 53,1

Tabel 3: Rekapitulasi skor

\begin{tabular}{lrrrr}
\hline $\begin{array}{l}\text { Masalah } \\
\text { JML }\end{array}$ & $1($ a) & $1(b)$ & $2(a)$ & 2(b) \\
\hline $\begin{array}{l}\text { Rata-rata } \\
10,06\end{array}$ & 2,84 & 1,91 & 3,18 & 2,12 \\
& $(70,97)$ & $(47,85)$ & $(79,57)$ & $(53,1)$ \\
$\begin{array}{l}(62,87) \\
\text { Stand.Dev }\end{array}$ & 1,52 & 1,16 & 1,38 & 1,18 \\
$\begin{array}{l}\text { M,38 } \\
\text { Minimum } \\
\text { 0 }\end{array}$ & 0 & 0 & 0 & 0 \\
$\begin{array}{l}\text { Maksimum } \\
4\end{array}$ & 4 & 4 & 4 & 4 \\
\hline
\end{tabular}


Keterangan: Bilangan yang dalam kurung pada rata-rata adalah konversi skala 100.

Hasil identifikasi TKBK siswasiswa kelas XI SMAN 2 Surabaya menunjukkan bahwa ada $80,1 \%$ termasuk TKBK 0 atau 1. Siswa yang termasuk TKBK 2 sebanyak 5,9\% ; siswa termasuk TKBK 3 sebanyak 8,6\%, dan hanya ada 5,4\% siswa dengan TKBK 4 (Tabel 4). Siswa dengan TKBK 4 memperoleh jumlah skor 16. Siswa yang demikian dapat digolongkan sebagai pemecah masalah yang baik (good problem solver) (Muir, Beswick, \& Williamson, 2008).

Siswa dengan TKBK 1 karena siswa tersebut mampu menyelesaikan masalah 1(a) atau 2(a) tetapi belum dapat menyelesaikan masalah 1(b) atau 2(b), serta cara yang digunakan masih didasarkan pada rumus-rumus yang dipelajari di kelas.

Tabel 4. Rekapitulasi TKBK

\begin{tabular}{lcr}
\hline TKBK & Jumlah Siswa & $\%$ \\
\hline $\mathbf{0}$ (sangat kreatif) & $\mathbf{2 3}$ & \\
$\mathbf{1 2 , 4}$ & & \\
$\mathbf{1}$ (kreatif) & $\mathbf{1 2 6}$ & \\
$\mathbf{6 7 , 7}$ & & \\
$\mathbf{2}$ (cukup kreatif) & $\mathbf{1 1}$ \\
$\mathbf{5 , 9}$ & & \\
$\mathbf{3}$ (kurang kreatif) & $\mathbf{1 6}$ & \\
$\mathbf{8 , 6}$ & & \\
$\mathbf{4}$ (tidak kreatif) & $\mathbf{1 0}$ & \\
$\mathbf{5 , 4}$ & & 100 \\
Jumlah & 186 & \\
\hline
\end{tabular}

Siswa belum menggunakan cara yang mengelaborasi pemahaman- pemahaman sebelumnya mengenai konsep-konsep yang terkait dalam masalah dan pengetahuan mengenai pendekatan/strategi penyelesaian masalah. Ada 1 siswa yaitu siswa no 24 yang memperoleh skor 4 di masalah 1(b) tetapi memperoleh skor 0 di masalah 2(b) karena tidak menuliskan penyelesaiannya. Ini karena siswa tersebut memfokuskan pada rumus untuk menyelesaikan masalah tersebut. Jika tidak ada rumus yang sesuai, maka siswa tidak dapat menyelesaikannya. Penyelesaiannya pada Masalah 1 dapat dilihat pada Gambar 1.

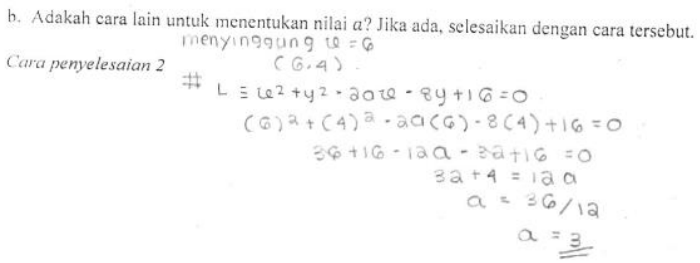

Gambar 1. Penyelesaian Siswa No 24 (TKBK 1) pada Masalah 1.

Lebih lanjut, ada 130 (69,89\%) siswa yang memperoleh skor 4 di masalah 2 tetapi ada $120(64,52 \%)$ siswa yang menjawab menggunakan rumus tertentu yang dipelajari di kelas dan hanya 10 $(5,38 \%)$ siswa yang menjawab dengan cara yang berbeda yaitu siswa-siswa dengan TKBK 4. Contoh rumus yang digunakan siswa no 8 (TKBK 1) di Masalah 2 dapat dilihat pada Gambar 2. 


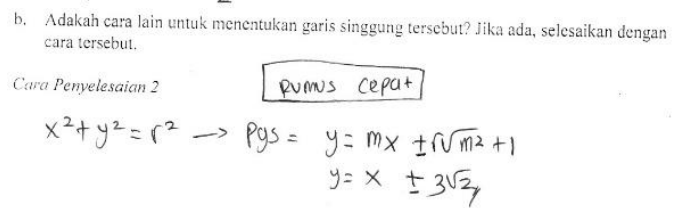

Gambar 2. Penyelesaian Siswa No 8 (TKBK 1) pada Masalah 2.

Hal berbeda dengan siswa no 7 (TKBK 4) yang mampu menyelesaikan dengan cara berbeda pada masalah 1 (Gambar 3). Begitu pula, siswa no 33 (TKBK 4) yang mampu menyelesaikan dengan cara berbeda pada Masalah 2 (Gambar 4).

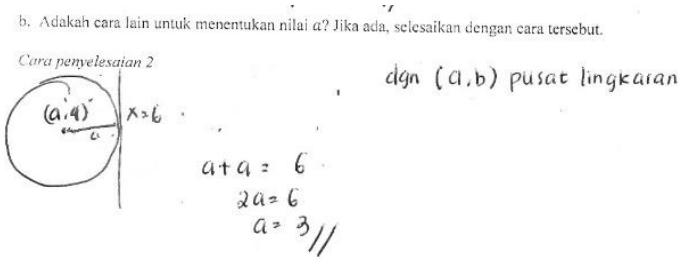

Gambar 3. Penyelesaian Siswa No 7 (TKBK 4) pada Masalah 1.

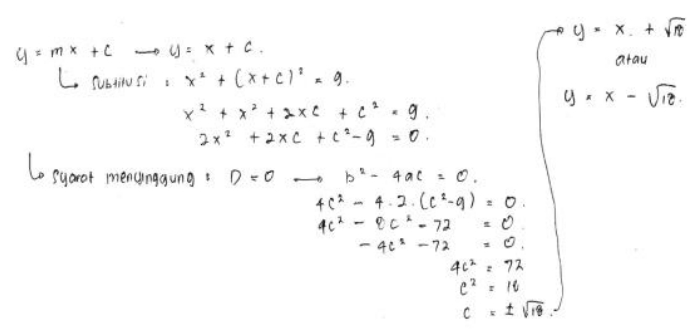

Gambar 4. Penyelesaian Siswa No 33 (TKBK 4) pada Masalah 2

Hasil penelitian ini menunjukkan bahwa sebagian besar siswa $(80,1 \%)$ memiliki TKBK 0 atau 1, sedangkan siswa dengan TKBK 4 sebanyak 5,4\%. Hasil ini sejalan dengan penelitian lainnya di kelas X-A SMAN 1 Gedangan Sidoarjo tahun ajaran 2013/2014 yang menunjukkan bahwa siswa-siswa dengan TKBK 0, 1, 2, 3 dan 4 secara berturut-turut sebanyak 44,44\%; 50\%; 2,78\%; 2,78\% dan 0\% (Mahendra, 2015). Dengan kata lain, 94,44\% siswa dengan TKBK 0 atau 1. Kedua penelitian juga menunjukkan bahwa siswa dengan TKBK 4 kurang dari 6\%. Siswa dengan TKBK 4 dapat digolongkan sebagai pemecah masalah yang baik. Hasil penelitian lainnya menunjukkan bahwa tidak ada siswa SMA yang tergolong pemecah yang baik (Mairing, 2017).

Hasil tersebut terjadi karena siswa-siswa berfokus kepada rumus untuk menemukan jawaban dari masalah-masalah tersebut. Siswa tidak berusaha memahami masalah dengan membentuk gambar mental dari masalah dan merepresntasikannya dalam bentuk tabel, grafik, atau gambar tertentu (Sternberg \& Sternberg, 2012). Pemecahpemecah masalah yang baik membayangkan masalah seolah-olah terjadi di hadapannya dalam membentuk gambar mental atau menggambar kejadian dari masalah (Mairing, Budayasa, \& Juniati, 2011)

Siswa juga tidak mengelaborasi pemahamannya terhadap masalah, pengetahuan tentang pendekatan/strategi pemecahan masalah, 
dan pengalaman sebelumnya dalam mengembangkan rencana penyelesaian masalah. Pemecah-pemecah masalah yang baik memanfaatkan pengalaman sebelumnya dalam memecahkan masalah untuk mengembangkan lebih dari satu rencana. Pemecah masalah yang baik menyatakan bahwa rencana penyelesaian masalah yang sedang dihadapi (waktu SMP) berasal rencana penyelesaian sebelumnya waktu SD. Salah satu pemecah masalah tersebut berkata "ya kalo kita menjumpai soal yang persis gitu, kita nggak perlu mikir lagi rencanarencana gitu, tapi langsung kita mikir, oh dulu saya pernah ngerjakan ini, rencananya gini." (Mairing, Budayasa, \& Juniati, 2012). Penggunaan rencana sebelumnya untuk menyelesaikan masalah yang sedang dihadapi disebut dengan pendekatan analogi dalam pemecahan masalah (Sternberg \& Sternberg, 2012).

\section{Kesimpulan}

Hasil penelitian menunjukkan bahwa rata-rata skor kemampuan siswasiswa tersebut dalam menyelesaikan masalah sebesar 10,06 (maksimum 16). Jika dikonversi ke skala 100 menjadi 62,87. Lebih lanjut, hanya ada 10 siswa $(5,4 \%)$ yang memperoleh skor maksimum atau memperoleh skor 4 di masalah 1(a), 1(b), 2(a) dan 2(b). Siswa-siswa yang demikian tergolong pemecah masalah yang baik.

Hasil serupa ditunjukkan melalui TKBK (Tingkat Kemampuan Berpikir Kreatif) siswa-siswa tersebut dimana yang tergolong sangat kreatif (TKBK 4), kreatif (TKBK 3), cukup kreatif (TKBK 2), kurang kreatif (TKBK 1) atau tidak kreatif (TKBK 0) secara berturut-berturut sebanyak $5,4 \% ; 8,6 \% ; 5,9 \% ; 67,7 \%$ dan $12,4 \%$. Dengan kata lain, $80,1 \%$ siswasiswa tersebut tergolong kurang kreatif atau tidak kreatif. Kondisi tersebut terjadi karena penyelesaian siswa-siswa difokuskan pada rumus-rumus yang dipelajari di kelas. Siswa-siswa belum merepresentasikan pemahamannya terhadap masalah dalam bentuk gambar atau tabel. Siswa-siswa tersebut juga belum memanfaatkan pengetahuan yang relevan, strategi/pendekatan pemecahan masalah, dan pengalaman pemecahan masalah sebelumnya untuk menyelesaikan masalah-masalah dalam penelitian ini.

\section{Pustaka}

Beck, P., Dworkin, L., Leinwand, S., Rios, J., Rainey, A., and Raith, L. 2000. Mathematics assessment: A practical handbook for grades 6-8. (W. S. Bush, and S. Tingkat... (Tri Diah) 
Leinwand, Eds.) Reston, VA: The National Council of Teachers of Mathematics, Inc.

Bush, W. S., and Greer, A. S. (Eds.). 1999. Mathematics assessment. A practical handbook for grade 912. Reston, VA: The National Council of Teachers of Mathematics Inc.

Charles, R., Lester, F., and O'Daffer, P. 1987. How to evaluate progress in problem solving. Reston, VA: The National Council of Teachers of Mathematics, Inc.

King, F. J., Goodson, L., and Rohani, F. 2016. Higher order thinking skills, , tersedia di http://www.cala.fsu.edu/files/hig her_order_thinking_skills.pdf., Diakses tanggal 30 Maret 2016.

Krulik, S., Rudnick, J., and Milou, E. 2003. Teaching mathematics in middle schools. A practical guide. Boston, MA: Pearson Education Inc.

Mahendra, Y. B. 2015. Proses berpikir kreatif siswa kelas XA SMA Negeri 1 Gedangan dalam memecahkan masalah matematika pada materi peluang dengan soal higher order thinking ditinjau dari tingkat berpikir kreatif. MATHEdunesa, 1(4).
Mairing, J. P. 2017. Kemampuan siswa SMA dalam menyelesaikan masalah sistem persamaan linear tiga variabel. Aksioma, 15-26.

Mairing, J. P., Budayasa, I. K., and Juniati, D. 2011. Profil pemecahan masalah peraih medali OSN. Jurnal Pendidikan dan Pembelajaran, 18(1): 65-71.

Mairing, J. P., Budayasa, I. K., and Juniati, D. 2012. Perbedaan profil pemecahan masalah peraih medali OSN matematika berdasarkan jenis kelamin. Jurnal Ilmu Pendidikan, 18(2): 125134.

Muir, T., Beswick, K., and Williamson, J. 2008. I am not very good at solving problems: An exploration of student's problem solving behaviours. The Journal of Mathematical Behaviour, 27(3): 228-241.

Polya, G. 1973. How to solve it (2 ed.). Princeton, NJ: Princeton University Press.

Polya, G. 1981. Mathematical discovery: On understanding, learning and teaching problem solving. New York, NY: John Wiley and Sons, Inc.

Posamenteir, A. S., and Krulik, S. 2009. Problem solving in mathematics grades 3-6, powerful strategies 
to deepen understanding. Thousand Oaks, CA: Corwin A SAGE Company.

Prastiti, T.D. 2009. Implementasi realistic mathematics education (RME) dengan memperhatikan gaya kognitif siswa dan pengaruhnya terhadap kemampuan komunikasi dan pemecahan masalah matematika SMP. Jurnal Pendidikan dan Pembelajaran (JPP), 16(1).

Prastiti, T.D. 2017. Pembelajaran digital untuk pengembangan berpikir kritis dan kemampuan pemecahan masalah matematika, tersedia di http://fkip.ut.ac.id/index.php/ber ita/379-ting-ix.

Sa'dijah, C., and Sukoriyanto. 2015. Asesmen pembelajaran matematika. Malang, Indonesia: UM Press.

Siswono, T. Y. 2008. Model pembelajaran matematika berbasis pengajuan dan pemecahan masalah untuk meningkatkan kemampuan berpikir kreatif. Surabaya, Indonesia: Unesa University Press.

Sternberg, R. J., and Sternberg, K. 2012. Cognitive psychology (6 ed.).
Belmont, CA: Wadsworth Cengage Learning. 
